\title{
Scorched Earth
}

\author{
In the Amazon basin, farmers and ranchers contest land use with environmental and indigenous groups. Does that \\ make widespread fires the inevitable 'new normal'?
}

$n$ $\mathrm{n}$ the middle of August, global news coverage picked up the extent of forest fires in the Amazon, spurred on by an afternoon of darkness over São Paolo and social media 'fury' at the supposed 'lack of news. However, the story had begun in earnest on 4 July, when Brazil's National Institute for Space Research (INPE) reported two thousand square kilometres of the Amazon basin had been deforested (largely through fire) in June.

Rainforest ecosystems are not normally conducive to naturally occurring wildfires, and what fires there are tend to be restricted to ground level. Fire is rather a much-used human tool for forest clearance (Nat. Plants 3, 17093; 2017). In its July announcement, the INPE reported that deforestation between August 2018 and June 2019 had increased $15 \%$ compared to the same period the previous year. Two weeks later, on 18 July, the INPE followed up with data showing that a further thousand square kilometres of Amazon basin was on fire in the first half of July alone, accelerating the deforestation and representing a $68 \%$ increase over the entirety of July 2018 (although it should be said that 2018 was a relatively wet and fire-free year).

The next day, Brazilian President Jair Bolsonaro, who was elected in 2018 with an explicit platform of demoting environmental protections and agencies, which he blames for slowing economic growth, called the INPE data about forest fires a 'lie' without providing evidence. He also said that European Union leaders criticizing his Amazon policies had an 'environmental psychosis', and demanded that INPE director Ricardo Galvão explain himself. Within two weeks, Galvão, despite having support from several scientific organizations including the Brazilian Academy of Sciences, was fired by Brazil's Minister of Science and Technology, Marcos Pontes. Pontes had tried to support INPE's data to Bolsonaro, but also defended restricting its publishing, which Bolsonaro felt was problematic for Brazil's image abroad.

This did not end the conflict between Brazil's President and his scientists. On 21 August, the INPE reported that
74,000 fires had broken out across Brazil (the highest number since 2013), half of which had begun in the previous month. By this point, the extent of deforestation a more significant figure than the fires was 300\% larger than in July 2018. Old news to the residents of São Paolo, Brazil's largest city, where two days before at 15:00, black smoke and clouds of ash rolled into the skies overhead, causing night-like conditions in the middle of the afternoon. The source of the smoke is largely believed to be fires burning 2,700 km away in the Amazon. Bolsonaro's response was to accuse, again without evidence, non-governmental and environmental organizations of deliberately setting fires and waging a 'war' against Brazil in order to 'cause problems'.

Few people doubt that the fires are actually the preserve of farmers and ranchers acting illegally to clear land, chiefly to produce cheap beef for the global market.

Around this time, the Amazon fires became a trending news item on social media, spurring memes and quotes about the 'lungs of the earth' being on fire, as well as counter-articles about how such a term is largely meaningless. Amongst those picking up the 'lungs of the earth' term were some of the world leaders gathering that weekend for the summit of seven largest advanced economies (G7) in Biarritz, France, including French President Emmanuel Macron and Canadian Prime Minister Justin Trudeau. On 26 August, the assembled leaders pledged $\$ 22$ million and tanker aircrafts to help fight the fires (a monetary offer that even Rainforest Alliance said was a token, symbolic gesture); however, this money was categorically rejected by Bolsonaro unless Macron apologized for comments that Bolsonaro felt reflected a colonialist mindset. Bolsonaro's chief of staff even said that failure to prevent the burning of Notre Dame cathedral in Paris earlier this year showed that Macron and France had no business lecturing Brazil about putting out fires.

One of the few politicians to generate goodwill during this time was Bolivian President Evo Morales, who, despite leading a relatively poor and landlocked country, pledged to hire or buy tanker planes to help fight the Amazon fires, which were also affecting Bolivia. By mid-September, some six million acres of forest had been set alight since August, nearly equal to the burned areas in Brazil, despite Brazil being eight times larger and holding vastly more of the Amazon basin.

Morales might be expected to be the ideological opposite of Bolsanaro with regards to forest conservation, as he was elected as a socialist and comes from indigenous heritage. Also, unlike Bolsonaro, Morales has accepted international assistance and was even filmed helping with fire-fighting. However, in 2016, Morales signed a law allowing a fourfold increase in land burning for farmers, and in July 2019, he allowed for 'controlled burns' in and around the forest areas that have now gone up in flames. Ideology, it would appear, does not always see the forest for the trees.

The eyes of the world, or at least of its press, seem to have turned away from the Amazon fires in recent weeks, whether because of political distractions, economic fears, news fatigue or simple resignation to this 'new normal'. But that resignation is exactly what fuels these 'unnatural disasters', as we called the rise of wildfires in an editorial two years ago (Nat. Plants 3 , 17124; 2017). While apparently 'wild' fires catch our attention, their underlying cause, deforestation, is well within our power to regulate. Yet we must be careful not to unfairly blame ranchers and farmers who are merely reacting to the choices they face on the ground: to starve or to set fires. Bolsonaro did not start the burning of the Amazon rainforest, but he is presiding over an inflection point in the existence of one of the great ecosystems on Earth. Stripping away environmental protections, encouraging illegal deforestation and ignoring or misrepresenting the work being done by scientists and NGOs will leave behind a charred landscape and call it 'the normal cost of business'.

Make no mistake, there is nothing normal about this.

Published online: 8 October 2019 https://doi.org/10.1038/s41477-019-0540-7 